\title{
An Environmental Assessment of Vernacular Housing in Banda Aceh, Indonesia
}

(Penilaian Lingkungan pada Rumah Vernakular di Banda Aceh, Indonesia)

Laina Hilma Sari, Izziah, Mirza Irwansyah, Erna Meutia

Department of Architecture, Syiah Kuala University, Banda Aceh, Indonesia laina.h.sari@gmail.com

\begin{abstract}
The presence of new buildings is currently seen to be dominated with minimalist style. The traditional and transitional houses have been gradually extinct. This study, therefore, assesses the vernacular housing in Aceh, Indonesia focusing on Banda Aceh and the surrounding areas. The vernacular houses evaluated in this study are the traditional, transitional and modern houses. The idea is to assess the environmental quality of those houses in term of local wisdom, embodied energy and thermal comfort. Since the local climate of Aceh is not significantly different from the majority of the lowland area in Sumatra or even Indonesia, this study can also be a reference in conducting similar studies.
\end{abstract}

Keywords: Vernacular housing, Aceh, embodied energy, thermal comfort

\begin{abstract}
Abstrak
Kehadiran bangunan baru saat ini dominasi dengan gaya minimalis. Rumah-rumah tradisional dan transisi telah secara bertahap punah. Oleh karena itu penelitian ini menilai perumahan vernakular di Aceh, Indonesia yang berfokus pada Banda Aceh dan sekitarnya . Rumah-rumah vernakular yang dinilai dalam penelitian ini adalah rumah tradisional, transisi dan modern. Lingkup dari penelitian in adalah penilaian kualitas lingkungan rumah dalam hal kearifan lokal, energi yang terkandung dan kenyamanan termal. Karena iklim lokal Aceh tidak berbeda secara signifikan dari sebagian besar daerah dataran rendah di Sumatera atau bahkan Indonesia, maka penelitian ini juga dapat menjadi acuan dalam melakukan penelitian serupa
\end{abstract}

Kata Kunci: Rumah vernakular, Aceh, Embodied energy, kenyamanan termal

\section{INTRODUCTION}

Vernacular architecture is architecture without architects. In environmental architecture, vernacular architecture becomes a guideline in designing building adaptive to the local climate. The adaptive characters are such as its ability in supplying comfort to the occupants, and being friendly to environment mostly through the materials used.

In tropics, vernacular houses appear with the large overhang to protect the house against the rain and shade the internal space from direct sunlight and heat; the openings faces north and south which is also designed to receive only the welcome sunlight. The design typically follows a template for structure grids. Local wisdom values are implied; for example close relationship among family members. In Aceh, it is currently very scarce to find these houses. They are mostly unoccupied or used as the museum or educative buildings. Once it is occupied, it is often modernized using concrete and glass. 
Based on the above background, this study assesses Banda Aceh as the case to explore the vernacular housing.

Banda Aceh is the capital city of Aceh province situated in $5^{\circ} 33^{\prime} 0^{\prime \prime} \mathrm{N} 95^{\circ} 19^{\prime} 0^{\prime \prime} \mathrm{E}$ which is about 8 meters above the sea level. This town is mostly surrounded by the coast and sea. The local climate is wet humid with average temperature $27^{\circ} \mathrm{C}$, relative humidity $78 \%$, wind speed $2 \mathrm{~m} / \mathrm{s}$ and the dominant of wind orientation faces southeast; the amount of rain is $100.6 \mathrm{~mm}$ which mostly falls in December and January (BMKG, 2008).

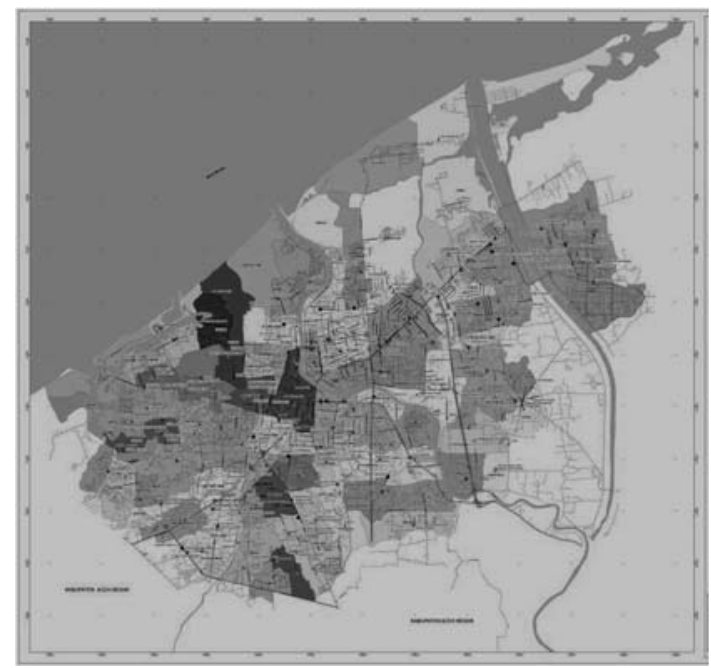

Figure 1. Map of Banda Aceh town

This study conducts an environmental assessment on the housing in Aceh which covers local wisdom, embodied energy and thermal comfort. The aim is to see how sustainable the houses in Aceh; and in what aspects of sustainability value could be sustained and implied in the current housing.
The study assessed several houses which are very common to see as the representative of the three house types, namely traditional, transitional and modern housing. The cases are named as follows:

RTD : Traditional house

RTS : Transitional house

RM : Modern house (due to the complexity of house styles, the house types selected in this study are detached - RM1, shop house RM2, and semi-detached- RM3)

The data collection was conducted through field survey, interview and using mechanical measurement explained in Table 1.

Tabel 1. Research Method

\begin{tabular}{|c|c|c|}
\hline Parameter & $\begin{array}{l}\text { Data } \\
\text { collection } \\
\text { Method }\end{array}$ & Indicator \\
\hline $\begin{array}{l}\text { Local } \\
\text { wisdom } \\
\text { applied in } \\
\text { the house }\end{array}$ & $\begin{array}{l}\text { Survey/ } \\
\text { observation } \\
\text { and interview }\end{array}$ & $\begin{array}{l}\text { Lay out plan } \\
\text { and house } \\
\text { façade, }\end{array}$ \\
\hline $\begin{array}{l}\text { Embodied } \\
\text { energy }\end{array}$ & $\begin{array}{l}\text { Survey/ } \\
\text { observation } \\
\text { for the } \\
\text { materials that } \\
\text { can be } \\
\text { directly } \\
\text { observed. }\end{array}$ & $\begin{array}{l}\text { Energy } \\
\text { density (MJ) }\end{array}$ \\
\hline $\begin{array}{l}\text { Thermal } \\
\text { Comfort }\end{array}$ & $\begin{array}{l}\text { Mechanical } \\
\text { measurement } \\
\text { and interview }\end{array}$ & $\begin{array}{l}\text { Air } \\
\text { temperature } \\
\left({ }^{\circ} \mathrm{C}\right) \\
\text { Relative } \\
\text { humidity (\%) }\end{array}$ \\
\hline
\end{tabular}

\section{RESEARCH METHOD}

Tesa Arsitektur Volume 15 | Nomor 1 | 2017 


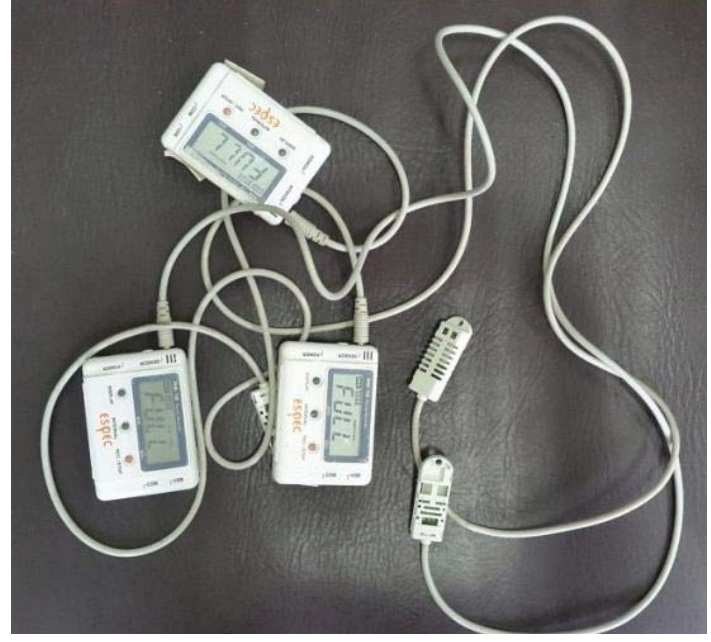

Figure 2. Thermal data logger utilized in the study

Air temperature and relative humidity were measured with thermal data loggerEspec RS 12 Thermorecorder (figure 2). The logger which was placed in the rooms without mechanical thermal comfort supplier such as, fan or air conditioner recorded the thermal data in 24 hours for each measures house.

\section{THEORITICAL REVIEW}

\section{Environmental and Architecture}

Sustainable development which has been broadly understood to define many aspects related to save the world from destructions. In Building, sustainability was the realization that a green approach to the built environment involved a holistic approach to the design of buildings; that all the resources that go into the building be they materials, fuels or the contribution of the users, need to be considered if sustainable architecture is to be produced. The move towards more sustainable architecture is growing every year. Development is considered sustainable if it is able to protect the environment (Bread for the World, Background Paper No. 129, Washington, DC, March 1993).

Being friendly to the environment is by maintaining the high quality of all sources without decreasing their quality that will be used by future generations (UNCSD, 2007). Therefore saving energy and zero emission are a critical issue to be considered. Thus, a sustainable building should be prepared from the very early process up to the demolition to get branded as green.

In this study besides learning from the ancient wise of local wisdom in being sustainable, thermal comfort and embodied energy are also evaluated. Buildings are responsible for a large amount of the total world annual energy consumption (Omer, 2008; Roaf, 2001) hence once it is well managed to reduce the energy use, it will help to save the environment from damage. Omer (2008) wrote that one way of reducing building energy consumption is to design buildings which are more economical in their use of energy for providing thermal comfort

Building materials must also be considered in sustainable housing, according to the following criteria: produced by socially and environmentally responsible companies; produced sustainably-harvested, extracted, processed, and transported efficiently and cleanly; low embodied energy, locally produced, made from recycled waste, made from recycled or renewable materials; durable; recyclable; nontoxic; efficient in their use of resources; reliant on renewable resources; and non-polluting (Chiras, 2004) 


\section{RESULT AND DISCUSSIONS}

\section{Local Wisdom Applied in the House}

Local wisdom is a sustainable characteristic that talks about adaptive integration with culture and local climate. In architectural term, local people's wisdom is interpreted as nature expressed in their houses. In this session, some selected houses from the three house type categories are discussed.
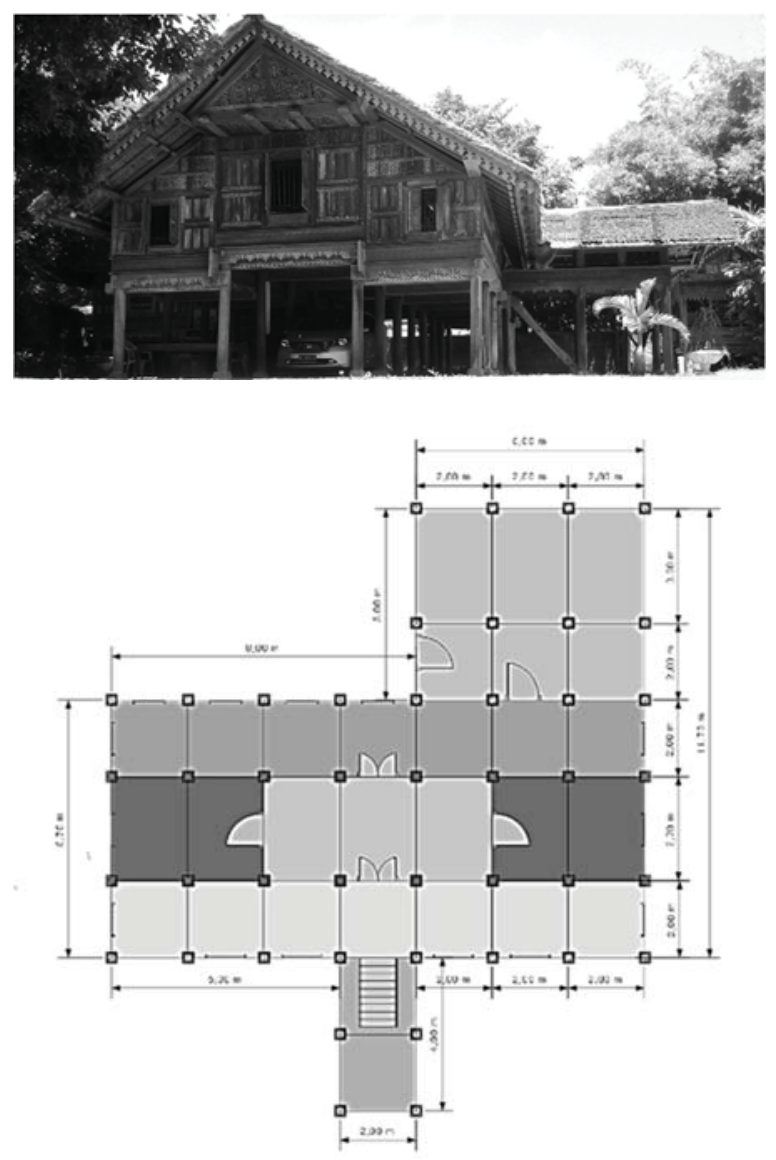

Figure 3. Acehnese traditional house, (RTD)

RTD is an Acehnese traditional house which is called rumoh Aceh. It has four parts, namely a living room, the middle room functioning as the connection between two bedrooms, the back room working as the family gathering place, and the last is the female room which is located either in east or west functioning as the parent sleeping room.

The local wisdom of the house is presented through the responding climatic house designs as follows:

- The long side with openings of the house facing north and south. It meets the recommended house design in tropics to avoid the direct solar radiation. While the short side facing west and east was a guidance to orient the kiblah (position of Mecca) during prayer which is about $150 \mathrm{C}$ from the west in the clockwise. This reflects the fact that the vast majority of Acehnese people that are Muslims.

- The large overhang of the roof shading the windows and almost all the external wall surfaces facing north and south. This sets the house in a cooler environment. It is even cooler by being heavily shaded by the surrounding trees and vegetation.

- $\quad$ Raising the floor to up about 1.8 meters above the ground. Besides protecting the occupants against wild animals and flooding, this construction is also intended to catch the higher wind to cool down the air temperature. It is also approached by getting the air from beneath the floor circulated throughout the house through the small air floor gaps. The space beneath the floor is also used to socialize with others and also as storage spaces

Tesa Arsitektur Volume 15 | Nomor 1 | 2017 
- Lots of large openings to let the air circulate throughout the house. The apertures are applied in the overall of building envelopes such as roof, wall, and floor.

- Limited inside partitions and less furniture to help the air freely circulate.

- Built in lightweight construction. Wall is wooden board and roof is made from thatch which is low in thermal capacity.
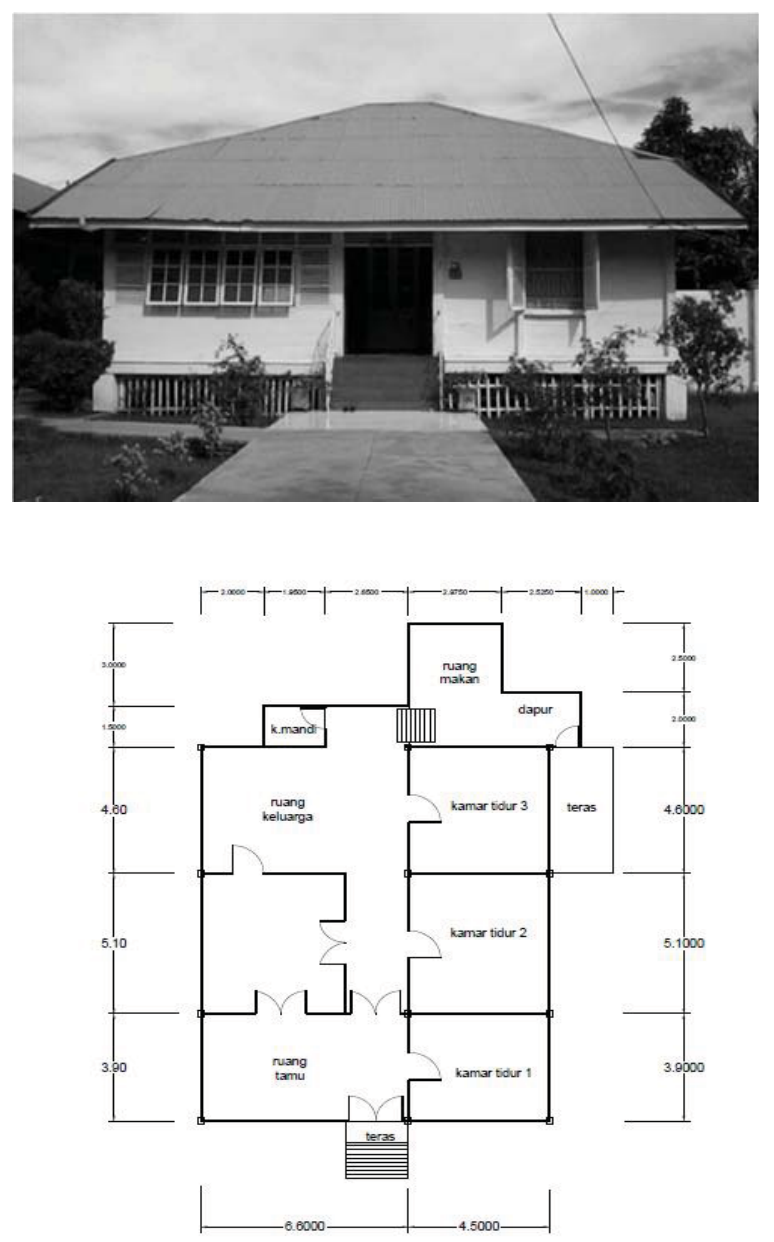

Figure 4. Transitional house (RTS)

RTS1 is the transitional house in Banda Aceh. This house is partially used as kindergarten (the front rooms) which is still running up to now. The rear parts are used as the living area. The layout plan shows that it adopts the traditional zoning pattern, namely front living space which is utilized as a living room, middle living space which is used as bedrooms zone and the rear living space which is utilized as family room such as dining room closed to the service area, i.e., kitchen and toilet. An additional bedroom at the front was built in recent time to accommodate the kindergarten activities. The majority of the material is timber. The modern materials used are glass for window and cemented floor for the kitchen.
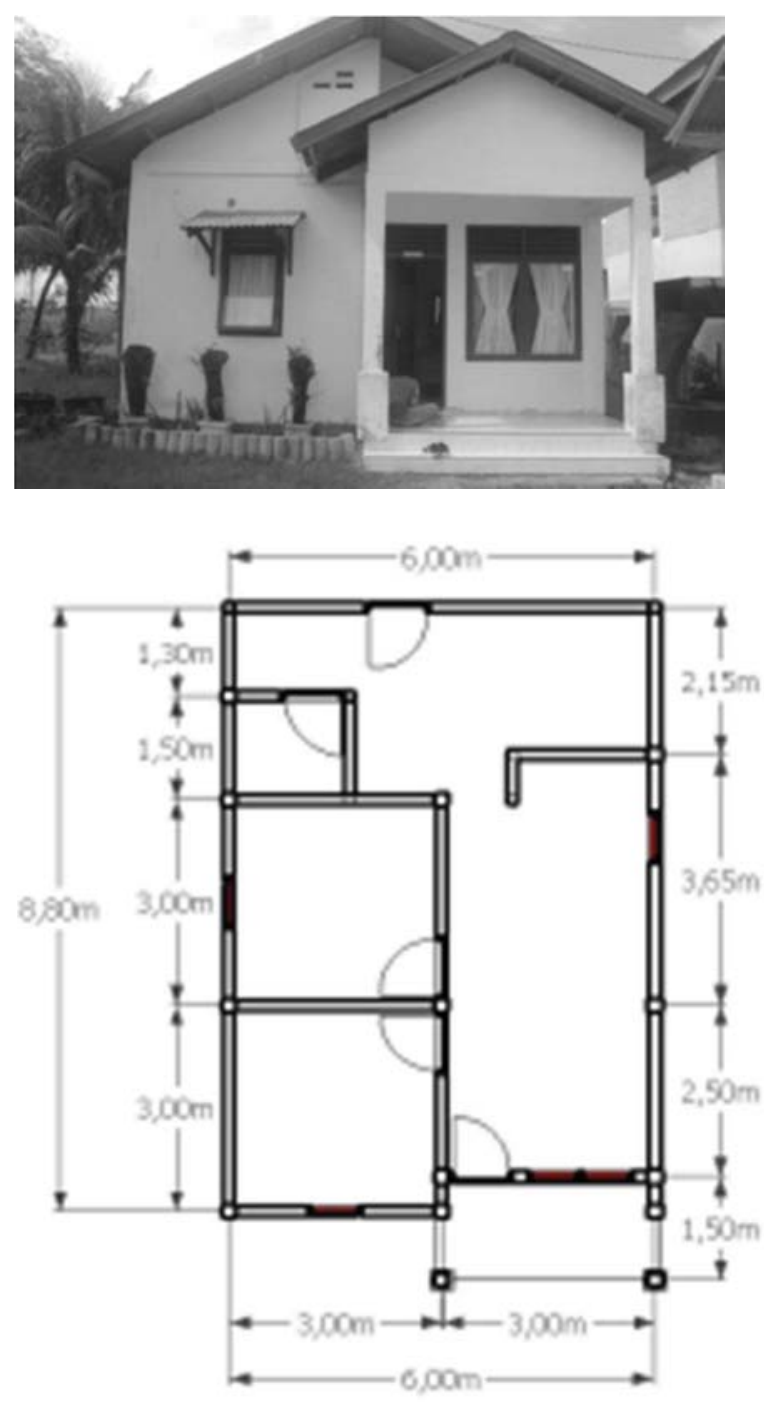

Figure 5. Detached modern house (RM1) 
RM1 is the house which was built by NGO for tsunami victims. It has a typical template of two bedrooms, a toilet and a small kitchen (36-52m2). It has been constructed a few years after the tsunami in 2004. The house was built in heavyweight material, i.e., brickworks and cemented/ ceramic floor.
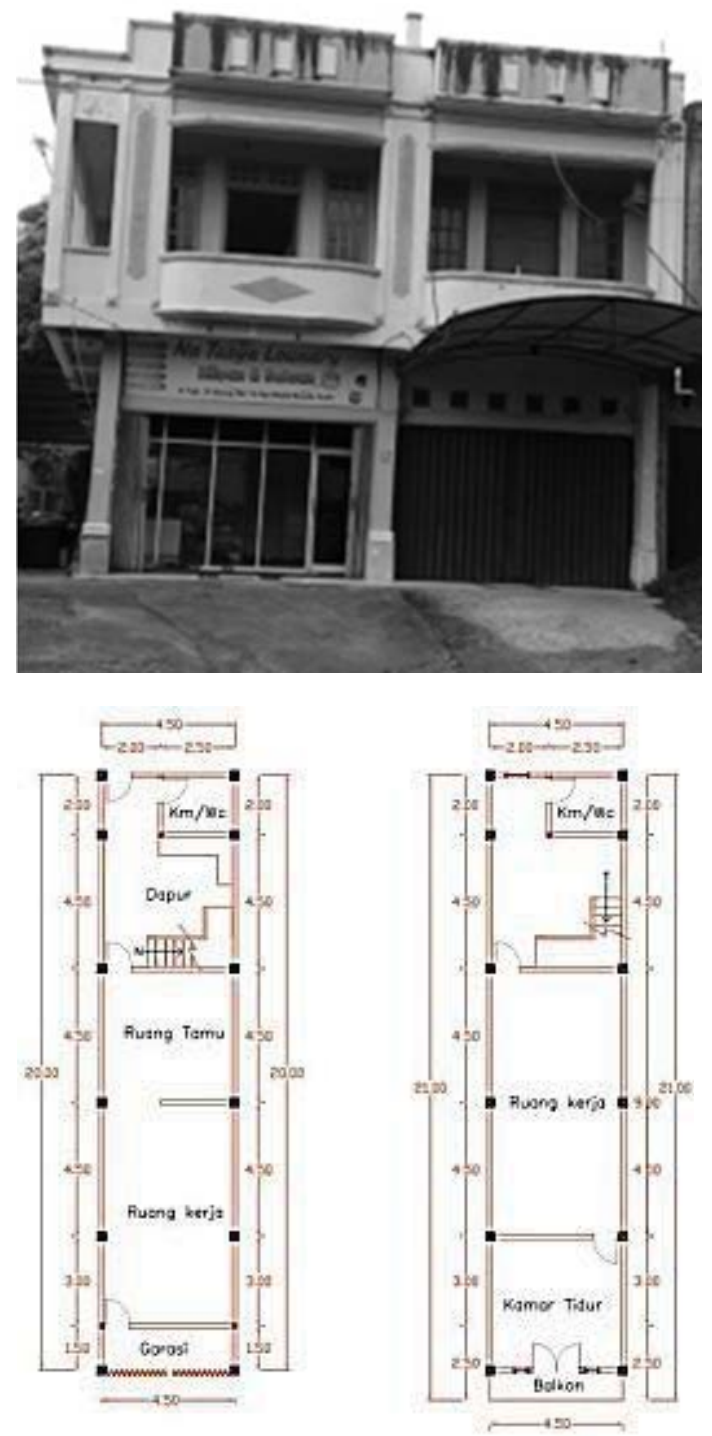

Figure 6. Shophouse (RM2)

$\mathrm{RM} 2$ is the typical commercial building built following the main street in Banda Aceh. The commercial activities are such as a shop or an office use the ground floor, while the upper floor is used as a living space (house).
The building materials commonly used in such building for both areas are brick wall, cemented floor or ceramic floor, glass window. Such this shophouse is often built in row causing limited openings which can only be accessed from the front and the rear.
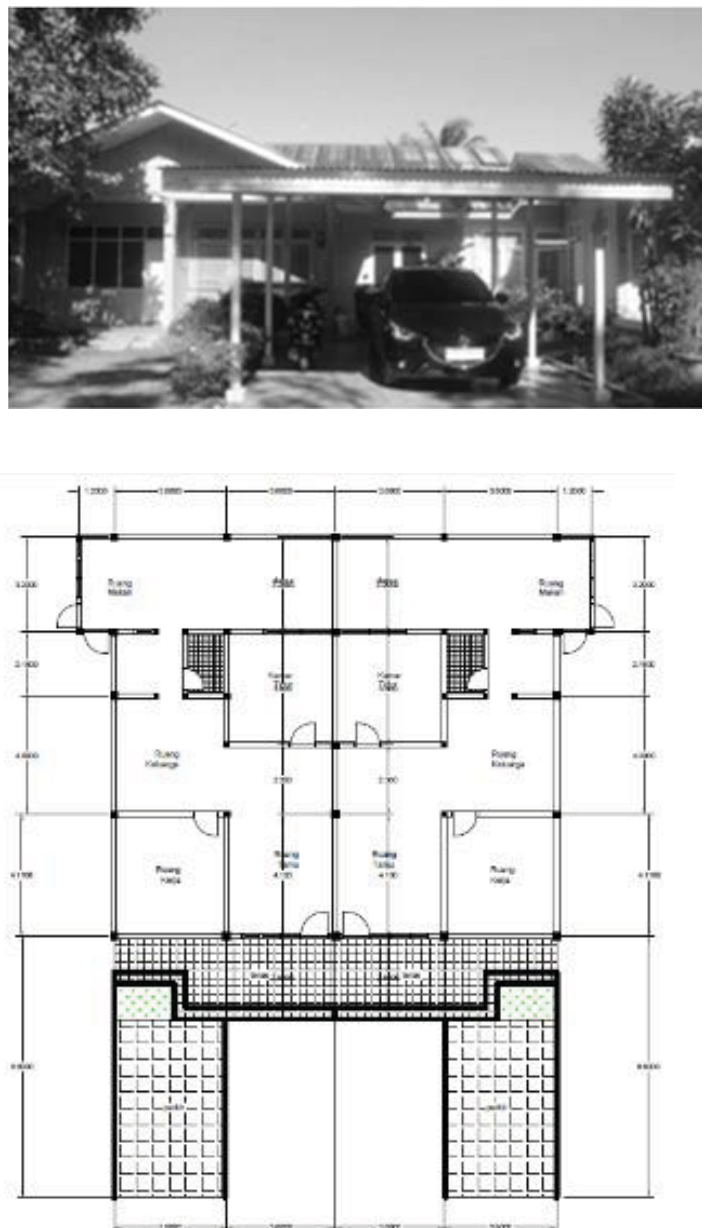

Figure 7. Semi-detached house (RM3)

RM3 is a couple home in Banda Aceh. This type of house is also quite typically built where two houses are built sharing the same roof structure construction and front terrace. Such house is usually built from brickwork

Tesa Arsitektur Volume 15 | Nomor 1 | 2017 
Embodied energy of the vernacular houses

Embodied energy is the energy consumed by all of the processes associated with the production of a building, from the mining and processing of natural resources to manufacturing, transport and product delivery. In this study, Processing Energy Requirement (PER) is used for the evaluation of the embodied energy of a building. PER is the energy consumption involved in the exploitation and processing of a building material. Energy coefficient in PER is calculated as $\mathrm{MJ} / \mathrm{kg}$ which is further calculated in finding energy density (Renping, 2006).

This study evaluated the thermal density of the traditional, transitional and modern houses using the following criteria:

Case 1: Traditional house which is built with original material.

Case 2: Transitional house which is built in raised floor type. Timber is applied as the wall material and zinc sheet as the roof material.

Case 3: Modern house which is usually built in brick wall, ceramic floor and zinc roof supported by light steel roof frame.

The thermal density is calculated based on the formula used by Wang (2006) which applied the main components of house i.e. roof, wall, and floor into the calculation. In this study the opening (window) is also calculated since different material of window is applied to different type of houses. Table 2, 3, 4 show the total energy density which is conducted through this following step: First, the weight of a component per square meter is calculated according to the construction of each member. Then, by multiplying the material's weight and its energy coefficient $(\mathrm{MJ} / \mathrm{kg})$, we will get the total energy per square meter, which is the density of energy of the main components. Table 2, 3 and 4 show the calculated parameters to obtain the total energy density in case of RTD, RTS, and RTM.

Table 2 shows that the traditional house has the little value of embodied energy compared with the transitional and modern house. The low energy coefficient of wood causes the lower value of thermal density. However, the scarcity of wood makes the price higher than using brick which has higher thermal mass. This dilemma is caused by the significant frequency of fire and illegal logging hitting Indonesian forest. This phenomenon cannot shift the idea of leaving the wood as building material and approaching the higher thermal densities materials which look cheaper than wood. Using brick primarily will harm the earth due to the earth excavation. The government has an enormous responsibility to keep the forest sustainable, such as by giving a strict rule for anyone doing logging to replant the forest and give a severe punishment for anyone neglecting the rules. The forest can grow even though it takes times, but the ground such as clay, sands are not growing which means that using them largely will denude and destroy the earth.

Tesa Arsitektur Volume 15 | Nomor 1 | 2017 
Tabel 2. Energy density of Traditional house

\begin{tabular}{|c|c|c|c|c|c|c|c|}
\hline component & construction & $\begin{array}{l}\text { square } \\
\text { (m2) }\end{array}$ & $\begin{array}{l}\text { volume } \\
\text { (m3) }\end{array}$ & $\begin{array}{l}\text { density } \\
(\mathrm{kg} / \mathrm{m} 3)\end{array}$ & $\begin{array}{l}\text { weight } \\
(\mathrm{kg})\end{array}$ & $\begin{array}{l}\text { energy } \\
\text { coefficient } \\
\text { (MJ/kg) }\end{array}$ & $\begin{array}{l}\text { energy } \\
\text { density } \\
\text { (MJ) }\end{array}$ \\
\hline Wall & $\begin{array}{l}\text { Wooden plank } \\
(0.025 \mathrm{~m}) \\
\text { Wooden plank }\end{array}$ & 1 & 0.025 & 705 & 17.63 & 3.5 & 61.69 \\
\hline Floor & $\begin{array}{l}(0.03 \mathrm{~m}) \\
\text { Rumbia Leaf * }\end{array}$ & 1 & 0.030 & 705 & 21.15 & 3.5 & 74.03 \\
\hline Roof & $\begin{array}{l}(0.2 \mathrm{~m}) \\
\text { Wooden rafter }\end{array}$ & 1 & 0.200 & 110 & 22.00 & 0.24 & 5.28 \\
\hline & $\begin{array}{l}(\varnothing 8 \mathrm{~cm}) \\
\text { Wooden louvere }\end{array}$ & 1 & 0.010 & 705 & 7.08 & 3.5 & 24.79 \\
\hline Window & $(0.025 \mathrm{~m})$ & 1 & 0.025 & 705 & 17.63 & 3.5 & 61.69 \\
\hline
\end{tabular}

*: represented by Straw bale

Tabel 3. Energy density of Transitional house

\begin{tabular}{|c|c|c|c|c|c|c|c|}
\hline component & construction & $\begin{array}{l}\text { square } \\
\text { (m2) }\end{array}$ & $\begin{array}{l}\text { volume } \\
\text { (m3) }\end{array}$ & $\begin{array}{l}\text { density } \\
(\mathrm{kg} / \mathrm{m} 3)\end{array}$ & $\begin{array}{l}\text { weight } \\
(\mathrm{kg})\end{array}$ & $\begin{array}{l}\text { energy } \\
\text { coefficient } \\
(\mathrm{MJ} / \mathrm{kg})\end{array}$ & $\begin{array}{l}\text { energy } \\
\text { density } \\
\text { (MJ/m) }\end{array}$ \\
\hline Wall & $\begin{array}{l}\text { Wooden plank } \\
(0.025 \mathrm{~m}) \\
\text { Wooden plank }\end{array}$ & 1 & 0.025 & 705 & 17.63 & 3.5 & 61.69 \\
\hline Floor & $(0.03 \mathrm{~m})$ & 1 & 0.030 & 705 & 21.15 & 3.5 & 74.03 \\
\hline \multirow[t]{2}{*}{ Roof } & $\begin{array}{l}\text { Zinc sheet }(0.0015) \\
\text { Wooden rafter }\end{array}$ & 1 & 0.002 & 3330 & 5.00 & 51 & 254.75 \\
\hline & $\begin{array}{l}(\varnothing 8 \mathrm{~cm}) \\
\text { Wooden louvere }\end{array}$ & 1 & 0.010 & 705 & 7.08 & 3.5 & 24.79 \\
\hline \multirow[t]{2}{*}{ Window } & $(0.025 \mathrm{~m})$ & 1 & 0.025 & 705 & 17.63 & 3.5 & 61.69 \\
\hline & & & & & \multicolumn{2}{|c|}{ Total Energy density } & 476.95 \\
\hline
\end{tabular}

Tabel 4. Energy density of Modern house

\begin{tabular}{|c|c|c|c|c|c|c|c|}
\hline component & construction & $\begin{array}{l}\text { square } \\
\text { (m2) }\end{array}$ & $\begin{array}{l}\text { volume } \\
\text { (m3) }\end{array}$ & $\begin{array}{l}\text { density } \\
(\mathrm{kg} / \mathrm{m} 3)\end{array}$ & $\begin{array}{l}\text { weight } \\
(\mathrm{kg})\end{array}$ & $\begin{array}{l}\text { energy } \\
\text { coefficient } \\
(\mathrm{MJ} / \mathrm{kg})\end{array}$ & $\begin{array}{l}\text { energy } \\
\text { density } \\
(\mathrm{MJ} / \mathrm{m})\end{array}$ \\
\hline & clay brick (15 & & & & & & \\
\hline Wall & $\mathrm{cm})$ & 1 & 0.150 & 950 & 142.50 & 0.97 & 138.23 \\
\hline \multirow[t]{2}{*}{ Floor } & Concrete $(3 \mathrm{~cm})$ & 1 & 0.030 & 2400 & 72.00 & 1.3 & 93.60 \\
\hline & $\begin{array}{l}\text { Ceramic tile } \\
(1 \mathrm{~cm}) \\
\text { Zinc sheet }\end{array}$ & 1 & 0.010 & 2500 & 25.00 & 2.5 & 62.50 \\
\hline \multirow[t]{2}{*}{ Roof } & $(0.0015 \mathrm{~m})$ & 1 & 0.002 & 3330 & 5.00 & 51 & 254.75 \\
\hline & $\begin{array}{l}\text { Light Steel roof } \\
\text { frame } \\
\text { Plywood }\end{array}$ & 1 & 0.008 & 7750 & 58.13 & 35 & 2034.38 \\
\hline Ceiling & $(0.003 \mathrm{~cm})$ & 1 & 0.003 & 705 & 2.12 & 10.4 & 22.00 \\
\hline \multirow[t]{2}{*}{ Window } & Glass $(0.0025 \mathrm{~m})$ & 1 & 0.003 & 2579 & 6.45 & 15.9 & 102.52 \\
\hline & & & & & \multicolumn{2}{|c|}{ Total Energy density } & 2707.98 \\
\hline
\end{tabular}

The transitional house(table 3) also shows a low value of thermal densities than it is in modern house. This can be a reference in

TERAKREDITASI : 2/E/KPT/2015

ISSN cetak 1410-6094 | ISSN online 2460-6367 choosing the building materials by using the low thermal densities materials more than the higher value ones. The sustainable materials 
can also be an alternative in reducing the thermal density materials. There are lots of selections of sustainable material such as paddy husks, wood husks, straw, etc. However, such materials are not commonly

\section{Adaptive Thermal Comfort}

Thermal comfort is defined as the condition of mind which expresses satisfaction with the thermal environment'. i.e. the condition when someone is not feeling either too hot or too cold (ISO 7730). The human thermal environment cannot be expressed in exact degrees. It is a personal experience dependent on many criteria which can be different from one person to another in the same place. The human body itself can adapt the thermal environment to achieve the comfort. Therefore many studies have been developed primarily concerning to find the range of adaptive thermal comfort either in free running building or air conditioned. The adaptive model introduced by Humphreys (1992), Nicol (1993) and Auliciems (1997), de Dear and Auliciems (1985) correlates neutral or comfort temperature and outdoor temperature. Therefore the comfort temperatures in different places are also various following the mean monthly outdoor temperature. In Indonesia, there are some studies carried out to search for comfort temperature. However, the studies were still limited to some areas.

This study is developed to see the inside and outside air temperature pattern which is correlated with the comfort temperature range. used and broadly accepted. It, therefore, needs more innovations to make those materials durable and reliable and also look attractive to be applied in the field.

There have not been studies finding comfort temperature in Banda Aceh conducted with adaptive approach, and it is not scientifically acceptable to adopt the comfort temperature which has different local climate. Therefore, Karyono's initial study in predicting the comfort temperature in Indonesia (Karyono, 2015) is utilized. Karyono (2015) collected some thermal comfort studies in Indonesia and from those found a regression equation of predicted comfort temperature (PCT) on the mean daily outdoor temperature as follows:

$P C T=0.749 T d+5.953$

$P C T$ is the predicted comfort temperature, and $T d$ is the average daily outdoor temperature. The coefficient determination of $R 2=0.38(r=0.61)$, and the regression is significant at a $95 \%$ confidence level.

Tablel 4: Comfort range of Banda Aceh

\begin{tabular}{llll}
\hline & $\begin{array}{l}\text { Max } \\
\left({ }^{\circ} \mathrm{C}\right)\end{array}$ & $\begin{array}{l}\text { Min } \\
\left({ }^{\circ} \mathrm{C}\right)\end{array}$ & $\begin{array}{l}\text { Avg } \\
\left({ }^{\circ} \mathrm{C}\right)\end{array}$ \\
\hline Td & 31.8 & 23.2 & 27.5 \\
Tco & 29.7 & 23.4 & 26.6 \\
\hline
\end{tabular}

Notes:

$T d$ : average daily outdoor temperature

Tco: comfort temperature

Based on equation 1, PCT of Banda Aceh is calculated by using the average daily outdoor temperature of $27.5^{\circ} \mathrm{C}$. The equation found that the predicted comfort temperature of Banda Aceh is $26.6^{\circ} \mathrm{C}$. To find the comfort 
range adaptively needs a further field survey which is not accommodated in this study. However, this study calculated the maximum and the minimum value of the average daily temperature into the equation. It gives a range where people are assumed to be able to adjust themselves naturally to get comfort either by adding or minimizing the number of clothing layer and adjust the metabolic rate through activities and food. Such range is not the same as range found from the real survey, yet the condition approaching upper, or lower level gives a warn that people will use the additional comfort supplier such as fan or AC in warm area and heater i.e. burning firewood in the cold area. Those ranges area as shown in table 4.

Figure 8 shows that RTD and RTS perform an almost similar pattern of inside air temperature. However, we can notice that the traditional house (RTD) gives slightly lower temperature compared with that of RTS. The temperature during the day (RTD and RTS) which is higher than the comfort zone is significantly caused by the light material, i.e., wood. Conversely, the evening temperature remains in the comfort zone. This situation can be solved by being outside during the day to get the free air and the shade of the vegetation. This is different from RM1 which has lower air temperature during the day and higher temperature during the night. It is due to the thermal mass of brickwork wall which stores solar energy during the day and reradiates it at night. This causes many modern houses install the air conditioner to cool down the inside air temperature during the evening.

Shophouse (RM2) shows the worst or highest air temperature which is out of the comfort range. This kind of house has limited openings which are only available on front and rear side. Left and right side are attached to another shop houses which creates large thermal mass which therefore creates higher inside air temperature. Semi detached house tends to provide higher temperature yet not as high as the storehouse.

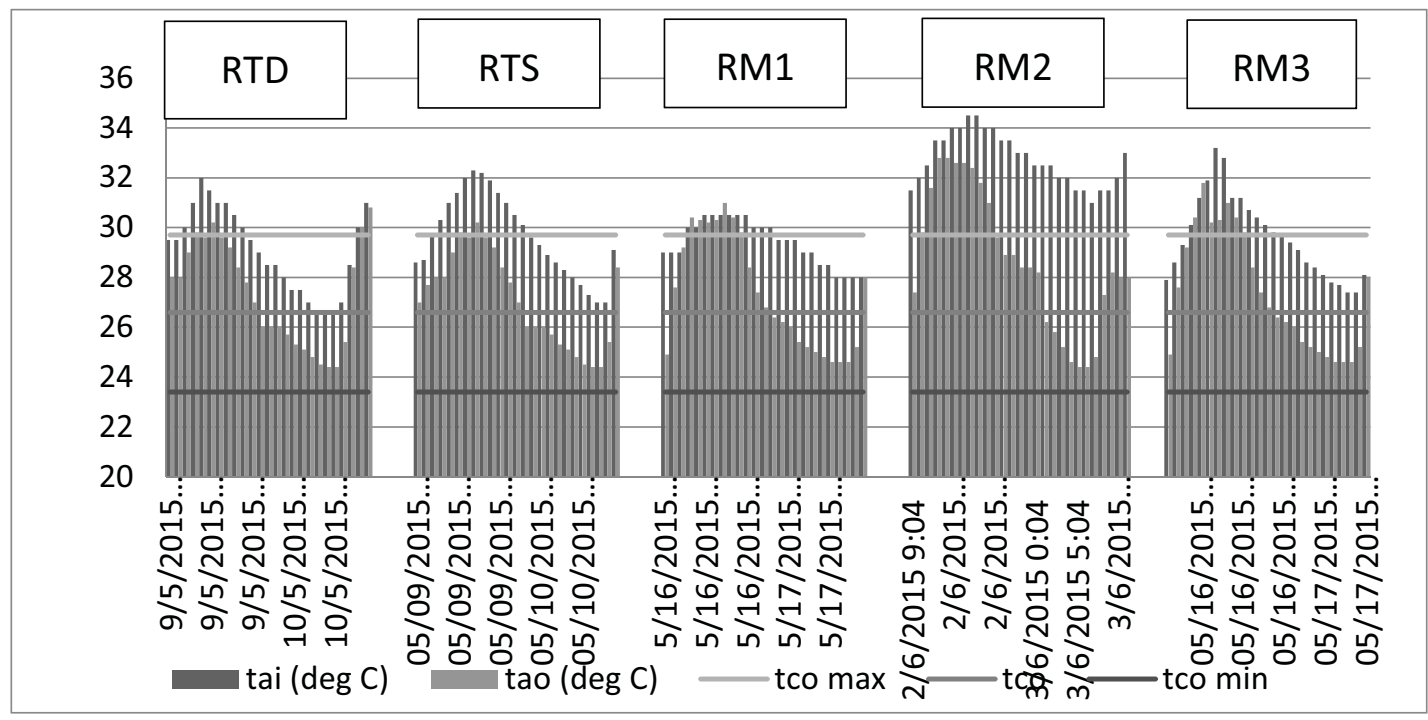

Figure 8: Air temperature of houses surveyed in Banda Aceh 


\section{CONCLUSION}

This study found that the traditional house is scarce to find. The transitional house is also not very easy to find where some houses have been used as an office or some other functions. The reasons are quite varied such as resource depletion making it tough and affordable for communities to build traditional vernacular house (Arboleda, 2006). The traditional house lay out evolves which can be seen from the transitional to the modern house. The transitional house in Banda Aceh shows to maintain the bedrooms in the middle row and keeps the front area as the public zone. While the modern house shows to move the bedroom to the front side equals to the guest area. And the bedroom door sometimes is easily seen from the guest room. The change of the house façade from raised floor house to be ground based house is also a significant change.

This phenomenon shows that the house layout cannot be sustained due to the social and culture reasons. More individualistic and less community-oriented makes people tend to leave the old style and make the more private house design. However, the embodied energy calculation shows that the building material in traditional and transitional house is able to provide the lower value which means it does not harm and destroy the earth. While in thermal comfort view, the modern house without wise understandings in design will create higher air temperature which contributes the need to use air conditioner to cool the internal environment.

The value of energy density in traditional and transitional house is also much lower than it is in modern house. It means that the house with low energy density gives little harm to environment. Therefore the study motivates us to keep the value of traditional house regarding building materials and the consideration in locating openings. While the traditional house layout cannot be sustained since the social living keeps changing which causes the change of human environment too.

\section{ACKNOWLEDGEMENT}

This study is part of STRANAS research which is funded by DIKTI. I, therefore, acknowledge DIKTI as the funding body to allow this research carried out well. My thanks are also expressed to Architecture department especially the students involved as the surveyor who spent their times quite long in completing the survey tasks.

\section{REFERENCES}

Auliciems (1997), Thermal Comfort Criteria for Indoor Design Temperatures in the Australian Winter. Architectural Science Review. 30

Arboleda, G. ( 2006), What is Vernacular Architecture? Available from world wideweb

(http://www.vernaculararchitecture.c om)

BMKG (2008) weather data of Banda Aceh and Takengon

Chiras, D. D., (2004) The Ecological Home,

A Complete Guide to Green

Building Options, USA: Chelsea

Green Publishing Company

de Dear and Auliciems (1985), Validation of the Predicted Mean Vote Model of Thermal Comfort in Six Australian Field Studies. ASHRAE Transaction, 81 (part 2B), 452-468

Humphreys, M. A (1992) Thermal Comfort Requiremnents, Climate and Energy. In the Second World Renewable Energy Congres, Brighton England: World Renewable EnergyCongres/ network

ISO 7730:2005-Ergonomics of the Thermal Environment-Analytical

Determination and Interpretation of Thermal Comfort Using Calculation of the PMV and PPD Indices and Local Thermal Comfort Criteria; International Organization for Standardization: Geneva, Switzerland, 2005

Karyono, T.H (2015), Predicting Comfort Temperature in Indonesia, an Initial Step to Reduce Cooling Energy Consumption, Buildings 2015, 5, 802-813; doi:10.3390/buildings5030802

Omer, A.M., (2008) ‘Energy, Environment and Sustainable Development, Renewable and Sustainable', Energy Reviews, 12, pp. 22652300

Nicol, F.J (1993) Thermal Comfort: A Hand Book for Field Studies toward An 
Adaptive Model. London: University of East London

Renping, W. (2006), An ecological assessment of the vernacular architecture and of its embodied energy in Yunnan, China, Building and Environment 41 (2006) 687697

Roaf, S.,(2001) Ecohouse: A Design Guide, London: Architectural press

UNCSD. (2007) Framing Sustainable Development, The Brundtland Report - 20 Years On. [online]. Available from:http://www.un.org/esa/sustdev /csd/csd15/media/backgrounder_br undtland.pdf 